y yo estaba pensando acerca del salero y el pimentero que estaban parados juntos sobre el mantelito.

Me preguntaba si ya serían amigos después de todos estos años o si todavía serían unos extraños

como tú y yo que somos conocidos y desconocidos al mismo tiempo-

yo en esta mesa con un plato con peras, tú recargado en el marco de una puerta en algún lugar cerca de las hortensias, leyendo esto.

\title{
LUNES
}

Los pájaros están en sus árboles,

el pan está en el tostador,

y los poetas en sus ventanas.

Están en sus ventanas

en cada sección de la mandarina tierralos poetas chinos mirando la luna, los poetas americanos observando los listones rosas y azules del crepúsculo.

Los oficinistas están en sus escritorios, los mineros abajo en sus minas, y los poetas mirando por sus ventanas tal vez con un cigarro, una taza de té, y quizás hasta una camisa de franela o una bata de baño estén involucradas. 
Los editores están jugando el ping-pong de las pruebas de página, yendo y viniendo de una página a otra, los chefs están cortando apio y patatas, y los poetas en sus ventanas porque es su trabajo por el cual les pagan nada cada viernes por la tarde.

Parece no tener importancia por cuál ventana aunque muchos tienen su favorita, ya que siempre hay algo que verun pájaro cogiendo una vara delgada, las luces de un taxi dando la vuelta, esos dos niños con gorras de lana cruzando la calle en diagonal.

Los pescadores se mecen en sus botes, los de telefonía trepan los postes redondos, los barberos esperan al lado de sus sillas y espejos, y los poetas continúan mirando fijamente el resquebrajado baño de los pajaritos o la rama derribada por el viento.

No es necesario aclarar ahora que lo que el horno es al panadero y la blusa manchada de fresas al tintorero, la ventana es para el poeta.

\section{Solo piensa-}

antes de que se inventara la ventana, los poetas tenían que ponerse una chaqueta y un gorro de invierno para salir o quedarse dentro con la mirada perdida en la pared.

Y cuando digo pared, no me refiero a una pared con tapiz a rayas o el dibujo de una vaca en la cenefa. 
Me refiero a una fría pared de piedra, la pared de un soneto medieval, el corazón de piedra de una mujer, la piedra atravesada en la garganta de su amante poeta.

\section{ESTATUAS EN EL PARQUE}

Hoy pensé en ti

cuando me detuve frente a una estatua ecuestre en medio de una plaza pública,

en ti que me habías enseñado el código de tan nobles poses.

Un caballo parado en dos patas, me dijiste, significa que el jinete murió en batalla.

Si una pata está alzada, el hombre sucumbió a las heridas en otra parte;

y si las cuatro patas tocan el piso, como en este casocascos de bronce en una base de piedraquiere decir que el hombre del caballo,

este con la atenta mirada fija en el cine cerrado de la acera de enfrente, murió de otra cosa que no fue la guerra

A la sombra de la estatua, me pregunté por los otros que simplemente caminaron por la vida sin caballo, montadura, o espada-

peatones que no podían más que poner un pie frente al otro. 